\title{
CROSS CARPETING AND THE CHALLENGES TO DEMOCRATIC CULTURE AND POLITICAL STABILITY IN NIGERIA'S FOURTH REPUBLIC
}

\author{
Ugo Chuks Okolie* \\ Department of Political Science, Delta State University \\ Abraka, Nigeria \\ *Email: ugookolie3@gmail.com
}

\begin{abstract}
Cross carpeting is an act of swapping political parties. It is an act of changing party allegiance or moving from one party to another. Cross carpeting in known by different nomenclature such as party hopping, party switching, party crossover, party defection, party decamping, floor crossing, canoe-jumping, political party prostitution and political nomadism. The spate of cross carpeting at all the levels of government in Nigeria is beginning to cause serious political tension, hostility and a source of worry to Nigerians. It is against this backdrop that this study seeks to examine the effect of cross carpeting on democratic culture and political stability in Nigeria's fourth republic. Cross - sectional research method was adopted and data was collected via a survey of 300 respondents in south - south geopolitical zone of Nigeria. Data collected were analyzed using correlation and linear regression analysis with the aid of Statistical Package for Social Science (SPSS) version 23. The
\end{abstract}

The Indonesian Journal of International Clinical Legal Education DOI: https://doi.org/10.15294/ijicle.v3i3.48270

Submitted: Dec 2, 2020 Revised: May 21, 2021 Accepted: July 19, 2021 Available online at https://journal.unnes.ac.id/sju/index.php/iccle (C) 2021 Authors. This work is licensed under a Creative Commons AttributionShareAlike 4.0 International License (CC BY-SA 4.0). All writings published in this journal are personal views of the authors and do not represent the views of this journal and the author's affiliated institutions. 


\section{Ugo Chuks Okolie}

findings of the study revealed that cross carpeting negatively and significantly impacts on democratic culture and political stability in Nigeria's fourth republic. On the basis of these findings, the study recommends among others that every political party should have ideologies, programme and policies which will serve as a compass to their members and discourage them from defecting to another party.

Keywords: Cross carpeting, political stability, democratic culture, political party, Nigeria

\section{INTRODUCTION}

The upsurge of cross carpeting at all the levels of government is beginning to cause serious political tension, hostility and a source of worry to Nigerians. The trend has become popular with lawmakers (especially those in the House of Representatives), members of House of Representatives and political parties passionately drumming up support to join tier party, leaving their statutory duties of law making and good governance to dwindle. ${ }^{1}$ Lending credence to the above, Mbati(argued that has become not only a norm but an increasingly permanent feature in the Nigeria's democratic culture. Cross carpeting and political instability are the greatest challenges confronting Nigeria's democracy. ${ }^{2}$ Cross carpeting from one political party to the other may seem graceful to those who are doing it, but it is rather harmful to their integrity but maybe profitable to their wives and personal aggrandizement which contaminates the future of democracy. ${ }^{3}$

Cross carpeting or what is known as party deflection in Nigeria pre-dates independence. Therefore, it is as old as Nigerian politics. When the first episode of cross carpeting occurred in 1951, it was a calculated strategy to stop Dr. Nnamdi Azikiwe, an Igbo man, from becoming the premier of Western Region. ${ }^{4}$ In the first Republic (1960-1966), personality rivalries between members of leadership of parties exert great

1 Okoye, I. (2014). Incessant Defection among Politicians Worries Lawyers. Retrieved from www.dailyposting/2014/incessant-defection-among-politiciansworried-lawyer;htm.

2 Nwanegbo, J.; Odigbo, J. \& Nnorom, K. (2014). Party defection and Sustenance of Nigerian Democracy. Global Journal of Humanities and Social Science, 14 (6), 1 8.

3 Aleyomi, M.B. (2013). Election and Politics of Party Defection in Nigeria: A Clue from Koji State. Covenant University Journal of Politics and International Affairs, $1(1), 113-130$.

4 Awofeso, O. \& Irabor, P.A. (2016). Party Cross-Carpeting in Nigeria's Fourth Republic: Cases and Causes. Journal of Public Administration and Governance, 6 (3), $31-43$. 
influence on cross carpeting. This was the case of the Action Group between Chief Ladoke Akintola and Chief Obafemi Awolowo which led to eventual splitting of the party into separate and distinct parties. By the Second and Third Republics, political patronage and money politics necessitated the need for politicians to cross from one party to the other. Cross carpeting of this scenario was that of Chief Akin Omoboriowo who was elected as the Deputy Governor of Ondo State under the platform of the Unity Party of Nigeria (UPN) but left the party to the National Party of Nigeria (NPN) to contest as its gubernatorial candidate. ${ }^{5}$

In Nigeria's Fourth Republic, the political youth's space saw the liberalization of the party system to multi-party system. This is evident with the registration of more than fifty to sixty political parties. ${ }^{6}$ However, out of the fifty to sixty parties in Nigeria, few of them are recognized in the country, while others are just minority groups. This is as a result $o$ the upsurge of cross carpeting among Nigeria's political actors (politicians) each time they perceived any treat to their political fortune. ${ }^{7}$ Therefore, the spate of cross carpeting and its challenges to democratic culture and political stability in Nigeria's Fourth Republic has raised a fundamental question on the sustainability of democracy in Nigeria. An attempt to answer this question is what this study has set out to achieve.

\section{STATEMENT OF PROBLEM}

In Nigeria polity, most politicians seem to decamp based on primordial interest and egoistic hedonism. Cross carpeting can only be healthy to the political system and democracy when it is built on the choice of ideology and it will be inimical to democratic culture and political stability if it is the function of primordial and egoistic interest. Right from inception of the Nigeria's Fourth Republic in 1999, the political system has witnessed a great upsurge of proliferation of mushroom political parties and cross carpeting saga, and this displays seem to be associated with the dissatisfaction of some politician in respect of administration and decision of the party's executive in areas of choosing candidate to represent the party. This dispensation has celebrated over two hundred decamped of members arising from parties' lack of internal democracy,

Sodeine, G. (2009). No Regret for my Past Roles in Politics - Omoboriowo. Daily Independent, May, 1.

6 Jinadu, A. (2014). "Political Parties and Democracy in Nigeria". In O. Obafemi, S. Egwu, O. Ibeanu \& J. Ibrahim (eds). Political Parties and Democracy in Nigeria. Kuru: National Institute of Policy and Strategic Studies.

7 Awofeso, O. \& Irabor, P.A. (2017). The Game Theory and the Politics of Cross Carpeting in Nigeria's Fourth Republic. Public Policy and Administration Research, $7(7), 66-72$. 


\section{Ugo Chuks Okolie}

and selfish desires of members. ${ }^{8}$ In Nigeria's Fourth Republic, no political party has clear ideology and this has accounted for incessant internal party crises which usually lead to defections. But in some cases, politicians still defect to other party even when there are no crises within their political parties. As a result of the above scenario, it is necessary to note that party defections in Nigeria are not restricted to one party, but has become a political norm in Nigeria's democracy. This political attitude has eroded the country's democratic pace and has created confusion and debate among academicians and voters in general. The problem this study intends to address includes the challenges posed by cross carpeting on democratic culture and political stability in Nigeria's fourth republic and the divergent reasons given for party defection in Nigeria.

This study attempts to find answer to the following specific questions:

1. What are the factors that motivate cross carpeting in Nigeria's fourth Republic?

2. Does cross carpeting obstruct the emergence of a viable opposition to the ruling part in Nigeria's Fourth Republic?

3. In there any significant relationship between cross carpeting and democratic culture in Nigeria's Fourth Republic?

4. Is there any significant relationship between cross carpeting and political stability in Nigeria's fourth Republic?

This study specifically identified the following objectives:

1. To examine the factors or reasons that motivate cross carpeting in Nigeria's fourth Republic

2. To determine if cross carpeting obstructs the emergence of a viable opposition to the ruling party in Nigeria's Fourth Republic.

3. To examine the relationship between cross carpeting and democratic culture in Nigeria's Fourth Republic.

4. To examine the relationship between cross carpeting and political stability in Nigeria's Fourth Republic.

The null hypotheses were formulated to guide the researchers in finding answers to the third and fourth research questions.

H1: There is no relationship between cross carpeting and democratic culture in Nigeria's Fourth Republic.

H2: There is no relationship between cross carpeting and political stability in Nigeria's Fourth Republic.

8 Dike, V. (2003). Nigeria and the Politics of Unreason: Assassinations, Decampments and Moneybags. Retrieved from http://www.nigerdeltacongress/articles/nigeria-and-thepolitics-of-unre.htm; Mbah, P. (2011). Party Defection and Democratic Consolidation in Nigeria, 1999 - 2009. Afro-Asian Journal of Social Sciences, 2(2), 1 - 21; Edet, L.I. (2017). Politics of Defection and its Implications on Nigeria's Democracy. International Journal of Humanities \& Social Science Studies, 3(5), 375 - 285. 
Ugo Chuka Okolie

\section{LITERATURE REVIEW}

\section{A. The Concept of Cross Carpeting}

Cross carpeting describes the circumstance whereby members (politicians/lawmakers) of a political party willingly leave their party for another whether for just or unjust reason. Cross carpeting is known by different nomenclature such as party hopping, party switching, party crossover, party defection, party decamping, floor crossing, canoejumping, political party prostitution, political nomadism, etc. In the view of Awofeso and Irabor ${ }^{9}$, cross carpeting is used to describe the practice where a person gives up allegiance to political entity in exchange for allegiance to another. In his work, Edet ${ }^{10}$ used the term 'politics of defection' in place of cross carpeting. He defined defection as an act of swapping political parties.

According to Aleyomi ${ }^{11}$, political party defection or party switching occurs as a result of personality clash, power tussles, crises or division within a given party, disagreement on party's position on an issue, realization of one's personal political ambition, party leaders reneging on agreed issues of the political party probably on power sharing formula and divergent views on the operations of a political party's philosophy and ideology. Lending credence to the above, Badejo and Obah-Akpowoghagha ${ }^{12}$ argue that lack of internal democracy, decision of the party's executives in choosing candidate to represent the party, and selfish desires of members. In addition, lack of viable party ideology, politics of godfatherism, constitutional ambiguity and loophole were also serious reasons for cross carpeting or party defection in Nigeria. Different reasons are given for politicians defecting. Whatever the reasons, the fact remains that defection from one political party to another is not a political crime even in the advanced politics, Omodia and Egwemi ${ }^{13}$ argued that defections are not uncommon. Lending credence

9 Awofeso, O. \& Irabor, P.A. (2017). The Game Theory and the Politics of Cross Carpeting in Nigeria's Fourth Republic. Public Policy and Administration Research, 7(7), $66-72$.

10 Edet, L.I. (2017). Politics of Defection and its Implications on Nigeria's Democracy. International Journal of Humanities \& Social Science Studies, 3(5), 375 - 285.

11 Aleyomi, M.B. (2013). Election and Politics of Party Defection in Nigeria: A Clue from Koji State. Covenant University Journal of Politics and International Affairs, 1 (1), $113-130$.

12 Badejo, B.T, \& Obah-Akpowoghagha, N.G. (2015). The Impact of Cross Carpeting and Multiplicity of Political Parties in Nigerian Democratic Process. Journal of African Studies and Development, 7 (8), 215 - 230.

13 Omodia, S.M. \& Egwemi, V. (2011). Party Politics and the Challenge of Political Representation in Nigeria. International Journal of Business and Social Science, 2(22), $270-275$. 


\section{Ugo Chuks Okolie}

to the above, Chang ${ }^{14}$ argued that cross carpeting or party defection occurs both in the established and in new democracies. However, the frequency of its occurrence varies from country to country. For instance, Evans and Hadley ${ }^{15}$ argued that on twenty (20) switches took place in the America congress from the 1940s to the 1990s. By contrast, cross carpeting is reported very frequently in most Africa new democracies including Nigeria.

Remarkably Desposato ${ }^{16}$ gives three reasons why cross carpeting warrant study. First, frequent cross carpeting makes it clear that parties to matter - otherwise politicians would not bother to switch parties. Second and most importantly, cross carpeting provides explanation for politicians underlying preferences, including their incentives for belonging to political parties. Third, cross carpeting poses a normative problem for representation in democracy. Therefore, addressing the issue of cross carpeting has become pertinent because of its consequences on the Nigerian nascent democracy. Besides, cross carpeting by nonpolitician no doubt poses a threat to the stability of the multi-party system.

\section{B. Democratic Culture}

An appropriate conceptualization of democratic culture must take the route of a fundamental understanding of the meaning of culture, an appreciation of its basic connotations. Culture has therefore been described as an omnibus terminology which can mean a variety of things, depending on the context in which it is used. ${ }^{17}$ In the view of Onuoha (2003), culture is seen as a process, a space, as well as an institutionalized instrument of defining oneself in relation to others and the world in general. Therefore, according to Busta (1967), democratic culture is a kind of culture that develops within a group that makes decisions democratically. It makes democracy more than just a decision-making process; instead it becomes a way of life, something you notice in all kinds of interactions between people.

Parekh ${ }^{18}$ also sees democratic culture as the desire and ability of individuals in a country to participate actively, individually and together, to the government of affairs affecting them. Democratic culture in our

14 Chang, A. (2009). Reelection Incentives and Defection: Party Switching in the Japanese Liberal Democratic Party. Japan: Institute of Political Science.

15 Busia, K. \& Hadley, N. (2010). Party Switching and the Goals of Members in US Congress. San Francisco, CA: Paper prepared for WPSA.

16 Desposato, S. (2006). Parties for Rent? Ambition, Ideology and Party Switching in Brazil's Chamber of Deputies. American Journal of Political Science, 50(1), $62-$ 80 .

17 Mkpa, M.A. (2001). "Social and Cultural Systems in Nigeria”. Inc. Ofuebe (ed) Dynamics of Social Studies. Enugu: New Generation Books.

18 Parekh, B. (1993). "The Cultural Particularity of Liberal Democracy". In H. David (ed.) Prospects for Democracy. London; Party Press. 
estimation therefore refers to a culture in which individuals have a fair opportunity to participate in forms of meaning-making that constitute them as individual liberty as well as collective self-governance. However, democracy is increasingly becoming a disoriented political philosophy. Hence in global perspective, democracy is currently in decline. Strong men in emerging democracies, populists and demagogues (in the other cases) have succeeded in unleashing such governance attacks on this system of government, so much that its natural movement has become the reverse gear. Consequently, it is becoming increasingly difficult to define democracy. ${ }^{19}$

The concept of democratic culture has more theoretical connotations than practical application. There is nowhere in the world where democracy is a republic of equals. Thus, socio-economic and political inequality is a prominent and permanent feature of democracy particularly in Nigeria where democracy has widened the gap between those who have access to power and public funds and those who do not. ${ }^{20}$ But a particularly valid name for democracy or democratic culture is a people-centered system of government. This centrality is however often misconceived by misguided politicians (mainly in emerging democracies) as being election-supremacy. Once the elections are over, the strong-men politicians would begin to greedily personify democracy and chose to dictate what happens in the polity and in their shenanigans, succeed in dominating the political space in the name of democracy. ${ }^{21}$ However, a democratic system of government ideally ensures that the government in power is accountable to the people and that such a regime and its personnel obey the laws of the land. ${ }^{22}$

\section{Political Stability}

Paldain (2016) defines political stability to cover four dimensions such as stable government, stable political system, internal law and external stability. Paldam argued that, these four dimensions are sufficient for the explanation of political stability. According to Sottilotta $^{23}$, the concept of political is very controversial concept. Sottilott argued that, a first broad definition of political stability refers to the absence of domestic civil conflict and widespread violence. In this sense, a country can be considered rid of instability when no systematic

19 Okeke, R.C. (2017). Political Culture, Democracy and Development in Nigeria. Science Arena Journal of Politics and Law, 2 (4) 1 - 9.

20 Ajayi, A. \& Ojo, E.O. (2014). Democracy in Nigeria: Practice, Problems and Prospects. Developing Country Studies, 4 (2), 107 - 125.

21 Okeke, R. C. (2017)., Op.Cit.

22 Egharevba, M.E. \& Chiazor, A.I. (2013). Political Corruption and National Development in Nigeria International Journal of Social Sciences and Humanities Review, 4 (1), $14-23$.

23 Sottilotta, C.E. (2013). Political Stability in Authoritarian regimes: Lessons from the Arab Uprising. A Working Paper 13. 


\section{Ugo Chuks Okolie}

attacks on persons or property take place within its boundaries. Secondly, classic interpretation equates stability with government longevity. Thirdly, political stability draws on the lack of structural change, that Is, the absence of internally or externally induced change in the basic configuration of a polity.

The international consulting firm Eursia Group cited (2013), sees political stability as the capacity of a country's political system to withstand internal or external chocks. In this sense, a broad operational definition of political stability should take concepts and indicators into account such as human development (as measured by the UN Human development Index), inequality (Grim Index); political legitimacy ( i.e. the more or less widespread support for the government, be it democratic or non-democratic), constraints on regime responsiveness (i.e. the economic constraints that government encounter in meeting the requests of their citizens as expressed, for instance, by the total stock of country's public debt); and regional/international integration (i.e. membership in international and regional organizations or he ratio of total foreign trade cover GDP). Therefore, a stable political science is one where the ruling government is favoured by the population and does not experience strong indicators social unrest. While there are challenges within any nation, and times of war or hardship are common, a stable political system is one than can withstand these occurrences without major societal upheaval and ongoing endurance of these circumstances. ${ }^{24}$ Political stability therefore, ensures improvement in employment, protect the basic right of citizens, promote the basic right and unity, provide basic infrastructure and services, electricity, water supply, healthcare and hence ensured increase in both local and foreign investment.

\section{THEORETICAL FRAMEWORK}

In our attempt to place this study in its proper perspective, the need for a theoretical framework of analysis is very fundamental. The theoretical framework of analysis adopted in this study is the Marxist theory of Postcolonial state. The theory is important because of its relative proficiency in analyzing post-colonial political economy. The state in the postcolonial periphery is a capitalist type of state, even though to some extent it is different from the state in advanced capitalist formations. ${ }^{25}$. According to the Marxist theory, the state is the product and a

24 Nomor, D.T. \& Iorember, P.T. (2017). Political Stability and Economic Growth in Nigeria. IOSR Journal of Economics and Finance, 8(2), 45 - 53.

25 Eme, O.I. \& Ogbochie, A. (2014). The Legl/Constitution Basis of Political Party Defection in Nigeria. Kuwait Chapter of Arabian. Journal of Business and Management Review, 3 (11), 19 - 34 
manifestation of the irreconcilability of class antagonisms. ${ }^{26}$ According to $\mathrm{Ekekwe}^{27}$, the state emerged so that antagonistic groups will not consume themselves in fruitless struggle over the ownership of means of production. Hence, the state emerged to moderate class struggle in advanced bourgeoisie states unlike in neo-colonial states where states are parts and parcels of class antagonisms it was supposed to moderate. Thus, post-colonial states rather than maintain or moderate economic relations, because an instrument of domination, exploitation and intimidation of the subjects". Similarly, Marx and Engels (1971: 38) insist that the executive of the modern state is but a committee for managing the common affairs of the whole bourgeoisie".

The Nigerian State as a post-colonial state or a periphery nation is characterized by these factors discussed above. Like other colonial states, Nigeria lacks the capacity to moderate the struggle which is pronounced between or among the various ethnic groups and states that make up Nigeria. Hence, political and economic imbalances exit among and between the various states or ethnic groups that make up Nigeria. These imbalances exist in almost every sector of the economy, hence most people feel marginalized - a situation which predisposes politicians to endless port de port called in this context political nomadism (cross carpeting). ${ }^{28}$ The Marxist theory of state is very significant to understanding and explaining the defection crises in Nigeria. Applying the theory, Eme and Ogbochie ${ }^{29}$ argued that those who have presided over the state have tended to personalized power and privatize collective national resources, while being excessively reckless in managing the affairs of the nation. Indeed, the state has become the prime mover of capitalist development and class formation, with all the associated contradictions that this won't to spew up.

Lending credence to the above, $\mathrm{Ake}^{30}$ argued that because the colonial economy largely shut out the indigenous elite from engaging in productive activities, politics became the only arena where relevance and influence could be gained at independence. And after independence in the periphery, there was a mere change of leadership position from foreigners to natives while the policies remained largely unchanged. The consequence was the chaotic and often bloody struggle for political

26 Lenin, V.I. (1984). The State and Revolution. Moscow: Progress Publishers.

27 Ekekwe, E. (1986). Class and State in Nigeria. Lagos Longman.

28 Udeuhele, G.I. (2015). Political Nonadism and its Implications on Political Development in Nigeria: A Critical Analysis. International Journal of African and Asian Studies, 1, 75 - 86.

29 Eme, O.I. \& Ogbochie, A. (2014). The Legl/Constitution Basis of Political Party Defection in Nigeria. Kuwait Chapter of Arabian. Journal of Business and Management Review, 3 (11), 19 - 34.

30 1Ake, C. (1996). Democracy and Development in Africa. Washington, D.C: The Booklings Institution. 


\section{Ugo Chuks Okolie}

power, the only means of material advancement. Politics naturally took the shape and fowl means ensured the winner took all, albeit temporarily. It was a game in which the modicum of decorum and reflection that would have allowed for some developmental inclination became absent.

Since Nigeria's transition to civil rule in 1999, the relevance of Ake's postulation on politics as an agency for instability has been consistently validated. Within the turbulent context of the Nigerian polity, the current gale of cross carpeting or defections sweeping across the country generally reflects that chaotic struggle for political power, which Ake had identified to be the bane of development. This is the light in which Nigerians should view the real estate of time and space that has been devoted to the cat flight between the all progressive congress and the People Democratic Party over the flurry of movement of members between either parties, the latest turf for the battle is the National Assembly where the APC is doing ball within its powers to harvest as many members as possible from the PDP. This resultant talks about the declarations of the seats of defecting senator vacant as well as the allegations of financial inducement in the house of representatives are reflection of representatives are reflection of the self portrait of the Nigerian politician as a character for perpetual search for morsel rather than ideas. ${ }^{31}$ It is true that section $68(\mathrm{~g})(1)$ of Nigeria constitution stipulates that politician may switch party if there are obvious evidence of division or when their party ideology is no more upheld by their party executives and if their parties deviate from their laid down principles. The fundamental question then is what divisions or ideological changes accounts for the recent defection of law makers at the lower house of legislature moved from the PDP to APC? This to end if not properly checked by stringent law will make mockery of the country emerging democracy

\section{CROSS CARPETING AND THE CHALLENGES OF DEMOCRATIC CULTURE AND POLITICAL STABILITY}

In Nigeria fourth Republic one of the major factors responsible for political instability in Nigeria fourth republic is the failure of the political class to sufficiently adhere to the basic tenants of democracy and constitutionalism. This was the contention of Narriman (2006) who noted that such situation has given rise to abuse of power brazen corruption

31 Eme, O.I. \& Ogbochie, A. (2014). The Legl/Constitution Basis of Political Party Defection in Nigeria. Kuwait Chapter of Arabian. Journal of Business and Management Review, 3 (11), 19 - 34. 
disregard for due process and the rule of law intolerance of political opposition abuse of the electoral process and the weakening of institutions. This contradicts the tenets of governance which presupposes the process of social engagement between the rulers and the ruled in a political community. ${ }^{32}$ The alarming rate of party defection or cross carpeting of politicians and instability within political parties occasioned by lack of internal democracy tends to obstruct democratic sustenance in Nigeria. The point must be made that although political party defections or cross carpeting cannot be abolished in politics anywhere. However, its occurrence can be minimized such that they occur on valid grounds such as lack of political space or divergence of opinions and ideology between the decamping members and the party. ${ }^{33}$

According Edet ${ }^{34}$, political party is one of the major institutions prerequisite for democratization and democratic sustenance. In advance democracies such as United States of America, Great Britain, Germany, France, etc, parties have been known to exist on sustained ideological base, not just platform for ascending to political power. Ideology according to Omotola ${ }^{35}$, constitute the hallmark of social political identification as well as mobilization and unifying factor. The concept of ideology seek to explain the empirical conditions under which certain concepts ,belief system, moral ideas ,and religious and scientific ideals became socially influential and in turn affect the course of human affairs (BEVIR 2010). Essentially, parties are formed by individuals that share the same political ideology, that hold a common vision and mission statement. Empirical studies have revealed that Fourth Republic political parties in Nigeria are composed of persons with different ideologies who do not only misunderstand themselves but are regularly feuding. ${ }^{36}$ This could be attributed to flawed and wobby foundations of these parties since 1960 which according to Omotola ${ }^{37}$, have been largely responsible for parties ideological bareness, it is emphasized further that complete absence of ideology in Nigeria political parties has accounted for the

32 Adejumobi, S. (2004). Democracy, Good Governance and Constitutionalism in Africa. In S. Odion-Akhaine (ed). Governance: Nigeria in the World. Lagos: Centre for Constitutionalism and Demilitarization.

33 Udo, J.I. (2014). The Strategy of Defections and Valueless Politics in Nigeria. Premium Times, Thursday, February 28, p. 8.

34 Edet, L.I. (2017), Op.Cit.

35 Omotola, S. (2009). Nigerian Parties and Political Ideology. Journal of Alternative Perspectives in Social Sciences, 1(3), 612 - 634.

36 Omotola, S. (2009). Nigerian Parties and Political Ideology. Journal of Alternative Perspectives in Social Sciences, 1(3), 612 - 634; Awofeso, O. \& Irabor, P.A. (2017). The Game Theory and the Politics of Cross Carpeting in Nigeria's Fourth Republic. Public Policy and Administration Research, 7(7), 66 - 72; Edet, L.I. (2017). Politics of Defection and its Implications on Nigeria's Democracy. International Journal of Humanities \& Social Science Studies, 3(5), 375 - 285.

37 Omotola, S. (2009). Nigerian Parties and Political Ideology. Journal of Alternative Perspectives in Social Sciences, 1(3), 612 - 634. 


\section{Ugo Chuks Okolie}

prevailing cross carpeting or party switching in the Nigeria fourth republic .In essence, Nigeria parties are bereft of effective part control over its members, Thus, the violation of entrenched fundamental principles, rules and regulations guiding the conduct and behaviour of every member of the party.

The issue of party defection or cross carpeting is becoming vital and a serious threat to democratic culture and political stability in Nigeria. $\mathrm{Mbah}^{38}$ affirmed that desperation to hold public office as a means of accumulating wealth make Nigerian politicians to cross -carpet without justifications. Cross carpeting therefore, has negative impact in the process of consolidating democracy under unwarranted situations of myriad defections or cross carpet among legislators the co-locus of the sovereignty of the nation state and guardian of the most populous democracy in Africa, governors, deputy governors and other party members to the ruling party. The trend tends to make caricature of our politics and particularly nascent democracy and belittles the spirit of opposition parties and democratic consolidation. ${ }^{39}$

In contemporary Nigerian politics, the phenomenon has emerged as a rather problematic to democratic culture and political stability. Udeuhele ${ }^{40}$ averred that countries such as Bangladesh, Pakistan, Malawi and Zambia, political party defection is regarded as sufficient threat to the stability of the political systems. Smith (2012) concurs to the above when he argues that in extreme cases of floor -crossing or cross carpeting, where the number of public representatives who have defected has been significantly high, such shifts of allegiance have led to the collapse of democratically elected governments, such as in Lesotho in 1997. Cross carpeting or party defections of political office holders who do not resign the first platform for coming to political position do not add value to the process of democratic consolidation. Edet ${ }^{41}$ also noted that the extreme cases of cross carpeting or political party defections have led to conflict fractionalization and killings of party members. Example, the killing of former Justice Minister, Bola Ige after he indicated his interest to resign his position in PDP - led government and return to help his party, alliance for democracy (AD) for the 2003 elections, the killing of PDP South - South leader, Harry Marshall after he cross - carpeted to All Nigeria People's Party (ANPP), the killing of former Deputy Speaker, Akwa Ibom State House of Assembly after he defeated from

38 Mbah, P. (2011). Party Defection and Democratic Consolidation in Nigeria, $1999-$ 2009. Afro-Asian Journal of Social Sciences, 2(2), 1 - 21

39 Udeuhele, G.I. (2015). Political Nonadism and its Implications on Political Development in Nigeria: A Critical Analysis. International Journal of African and Asian Studies, 1, 75-86.

40 Ibid.

41 Edet, L.I. (2017). Politics of Defection and its Implications on Nigeria's Democracy. International Journal of Humanities \& Social Science Studies, 3(5), 375 - 285. 
PDP to All Progressive Congress (APC) to contest 2015 general elections for the state House of Assembly, etc., are all clear indications that party politics in Nigeria is not rooted on ideological democratic principles. Aleyomi $^{42}$ concluded that the general view or rationale for party defection is not entirely wrong, but in a situation where the ruling party repeatedly enjoys a landslide victory or where the whims and caprices of a political party belong to a single or group of dictators by not allowing internal democracy to overrule personal interest is injurious to any democracy.

\section{METHODOLOGY}

This study examined cross carpeting and the challenges to democratic culture and political stability in Nigeria's Fourth Republic. A descriptive survey design was adopted and data was collected via a survey of 300 respondents in South - South-geopolitical zone of Nigeria. The questionnaires were distributed according to the respondents' experience in the field of politics/political science. Out of the 300 copies of the questionnaire administered, 243 were retrieved, giving us a response rate of $81.0 \%$ as shown in the table below.

\section{Model Specification}

Given that this study has two dependent variables, we formulate two models as specified below:

\section{Model One}

The first model has the following mathematic functions:

$\mathrm{DC}=\mathrm{f}(\mathrm{CC})$

Econometrically, the model was specified as:

$\mathrm{DC}=\mathrm{Fo}+\beta_{1} \mathrm{CC}+\Sigma \mathrm{t}$

\section{Model Two}

The second model has the following mathematical functions.

$\mathrm{PS}=\mathrm{f}(\mathrm{CC})$

Econometrically, the model was specified as:

$\mathrm{PS}=\mathrm{d}_{0}+\mathrm{d} 1+\Sigma \mathrm{t}$

Where

$\mathrm{CC}=$ Cross carpeting

$\mathrm{DC}=$ Democratic Culture

PS $=$ Political Stability

$\mathrm{P}_{0}=$ Constant

$\beta_{1}<==$ Coefficients and a prior sings of independent variables

$\Sigma \mathrm{t}=$ Error term

42 Aleyomi, M.B. (2013). Election and Politics of Party Defection in Nigeria: A Clue from Koji State. Covenant University Journal of Politics and International Affairs, $1(1), 113-130$. 


\section{Ugo Chuks Okolie}

From the above, the apriori expectations of the parameters of model one and two will be:

Model One:

$\beta_{1}<0$

Model Two:

$\mathrm{d}_{1}<0$

Table 2: Distribution of Questionnaire and response Rate

\begin{tabular}{lllll}
\hline s/n & $\begin{array}{l}\text { South } \\
\text { South State }\end{array}$ & $\begin{array}{l}\text { Questionnaire } \\
\text { distributed }\end{array}$ & $\begin{array}{l}\text { Questionnaire } \\
\text { retrieved }\end{array}$ & $\begin{array}{l}\text { Percentage } \\
\text { retrieved }\end{array}$ \\
\hline 1 & Delta & 50 & 47 & 15.7 \\
2 & Rivers & 50 & 36 & 12.0 \\
3 & Bayelsa & 50 & 43 & 14.3 \\
4 & Edo & 50 & 45 & 15.0 \\
5 & Akwa Ibom & 50 & 37 & 12.3 \\
6 & Cross Rivers & 50 & 35 & 11.7 \\
\hline & Total & $\mathbf{3 0 0}$ & $\mathbf{2 4 3}$ & $\mathbf{8 1 . 0 \%}$ \\
\hline
\end{tabular}

\section{RESULTS AND DISCUSSION}

Table 3: Electorates responses on whether cross carpeting obstructs the emergence of a viable opposition to the ruling party in Nigeria's Fourth Republic

\begin{tabular}{lll}
\hline S/N & Category & Percentage \\
\hline 1 & Strongly Agreed & 68.3 \\
2 & Agreed & 28.5 \\
3 & Neither Agreed or Disagreed & 3.2 \\
\hline & Total & $\mathbf{1 0 0 . 0}$ \\
\hline
\end{tabular}

Source: from the questionnaire administered

Table 3, revealed that cross carpeting obstructs the emergence of a viable opposition party to the ruling party in Nigeria's Fourth Republic. Out of the total respondents, it was observed that $68.3 \%$ strongly agreed and $28.5 \%$ agreed while only $3.2 \%$ of the respondents neither agreed nor disagreed. This is in partial agreement with the findings of previous study conducted by Badejo and Obah-Akpowoghagha (2015).

Table 4: Factors Responsible for Cross Carpeting in Nigeria's Fourth Republic

\begin{tabular}{llll}
\hline s/n & Variables & Frequency & Percentage \\
\hline 1 & $\begin{array}{l}\text { Lack of internal } \\
\text { democracy }\end{array}$ & 33 & 13.6 \\
2 & Ideological differences & 51 & 21.0 \\
3 & Lack of party discipline & 17 & 7.0 \\
4 & $\begin{array}{l}\text { 'Get-rich-quick' } \\
\text { syndrome }\end{array}$ & 37 & 15.2 \\
5 & Unresolved differences & 30 & 12.3
\end{tabular}


Ugo Chuka Okolie

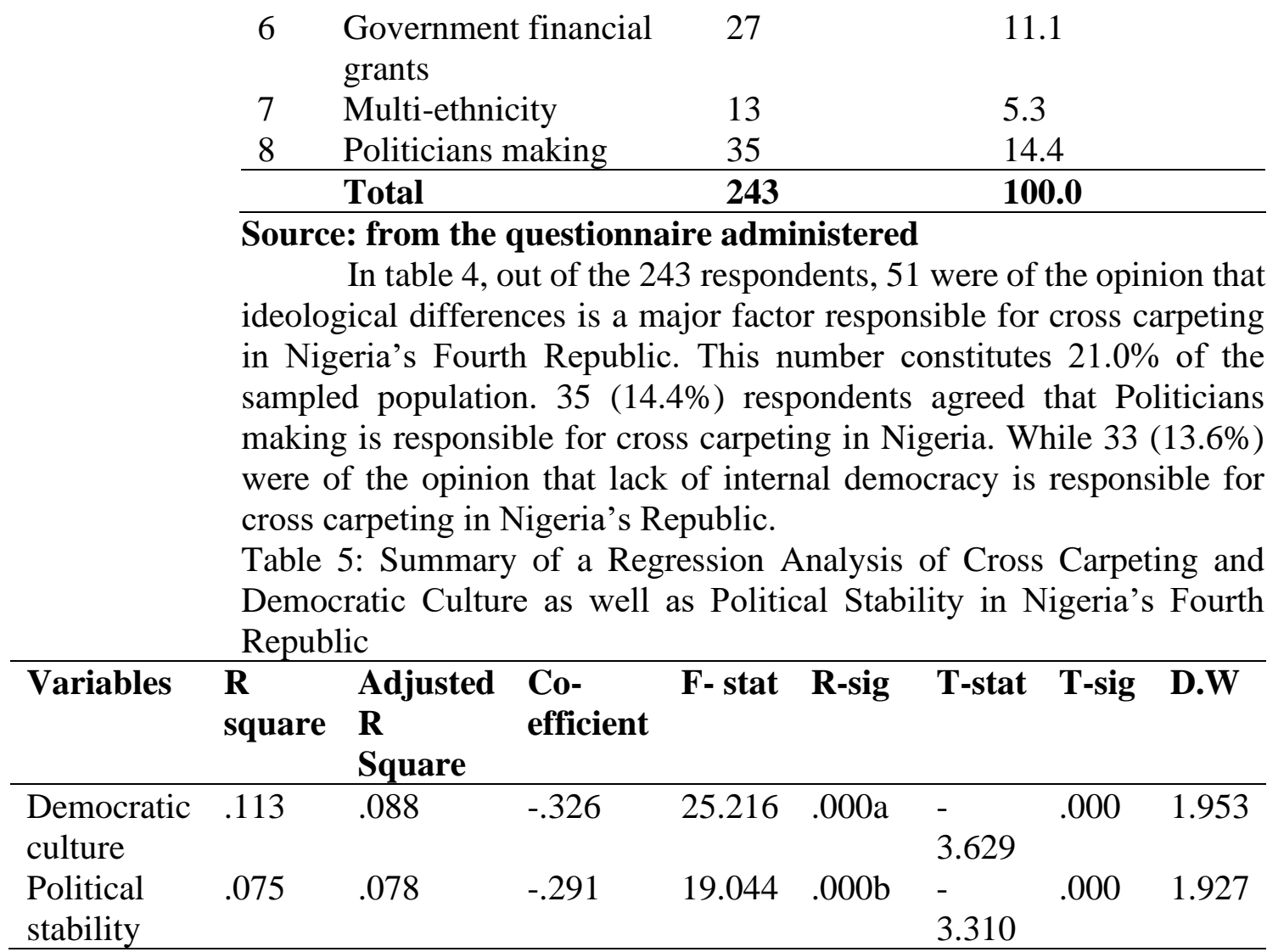

\section{Source: Researchers' fieldwork, 2020}

In table 5, drawing on the model summary displayed by the regression analysis, we observed that $\mathrm{R}$ - squared value which is the coefficient determination was .088 for the impact of cross carpeting on democratic culture in Nigeria's fourth Republic. This value means that cross carpeting or decrease in democratic culture in Nigeria's fourth republic while the remaining $88.7 \%$ causes of change in democratic culture in Nigeria's Fourth Republic are explained by other elements not included in the model, but taken care of by the error the terms. When coefficient of determination was adjusted for the degree of freedom it yielded .088 or approximately $8.8 \%$. This indicated that cross carpeting account approximately $8.8 \%$ of systematic (change in democratic culture after adjustment to degree of freedom. The Durbin -Watson statistic, which is 1.953, implies absence of serial autocorrelation in the regression analysis and the model can be relied upon in making policies related to the subject matters.

The F-statistic test of 25.216 at prob. (sig.) $=.000^{\mathrm{a}}$ conducted at $5 \%$ level of significant depicted in the regression results revealed that overall, there exist statistically significant linear relationship between cross carpeting and democratic culture in Nigeria's fourth republic. 


\section{Ugo Chuks Okolie}

Similarly, the t- statistic of -3.627 at $\mathrm{p}-$ value (sig.) of .000 obtained in the model for democratic culture which is less than $5 \%$ level of significant also indicated, that there is significant relationship between cross carpeting and democratic culture in Nigeria's fourth republic. The coefficient of -.326 further indicated that one percent increase in cross carpeting result in 32.6 percent decrease in democratic culture in Nigeria's fourth republic.

Also, from the model summary displayed by the simple regression analysis above, it was observed that R-squared value which is the coefficient determination was .075. This implies that cross carpeting explains only $7.5 \%$ of increase or decrease in political stability in Nigeria's fourth republic, while the remaining $92.5 \%$ causes of change in political stability are explained by other elements not included in the model, but taken care of by the error terms. The adjusted $\mathrm{R}^{2}$ value which was .078 in the simple regression model further indicated that coefficient of determination when adjusted for the degree of freedom yielded approximately $7.8 \%$, hence the model can be relied upon in making policies in since the cross carpeting accounted for approximately $7.8 \%$ of systematic (change) in political stability after adjusting the model of degree of freedom. The Durbin - Watson statistic of the model which shows 1.927 implies absence of serial autocorrelation in the regression analysis. The $\mathrm{F}-$ statistic test of 19.044 at prob. (sig.) $=.000^{\mathrm{b}}$ conducted at $5 \%$ level of significant depicted in the regression results revealed that overall, there exists statistically significant linear relationships between cross carpeting and political stability in Nigeria's fourth republic. Similarly, the $\mathrm{t}-$ statistics of -3.310 at $\mathrm{p}-$ value (sig.) of .000 obtained in the model which is less than 5\% level of significance further confirm a significant relationship between cross carpeting and political stability in Nigeria's fourth republic. Similarly, the $\mathrm{t}-$ statistics of -3.310 at $\mathrm{p}-$ value (sig.) of .000 obtained in the model which is less than $5 \%$ level of significance further confirm a significant relationship between cross carpeting and political stability in Nigeria's fourth republic. The coefficient of - 291 in the model indicated that one percent increase in cross carpeting result in $29.1 \%$ percent decrease in political stability in Nigeria's fourth Republic. These finding is in agreement with the views of Desposato (2006); Mbah (2011); Eme \& Ogbochie (2014); Nwanegbo et al. (2014); Udo (2014); Badejo \& Obah-Akpowoghagha (2015); Awofeso \& Irabor (2016); Awofeso \& Irabor (2017).

\section{VIII.CONCLUSION AND RECOMMENDATIONS}

The study showed that cross carpeting obstructs the emergence of a viable opposition party to the ruling party in Nigeria's Fourth Republic. 
Also the study have revealed through its perceived findings that cross carpeting have a strong and negativerelationship with democratic culture and political stability in Nigeria's fourth republic, and that cross carpeting negatively and significantly impacts on democratic culture and political stability in Nigeria's fourth republic. In addition to this, the study concluded that the practice of cross carpeting or party defection is not new in the country's political landscape, the recent development established beyond reasonable doubt that politics in Nigeria is totally bereft of ideological commitment to the welfare of the people. It could be stated that cross carpeting and ideological confusion in the present republic constitute a major challenge to democratic culture and political stability. Politicians in Nigeria defect from one party to another not on the basis of ideological differences, but on selfish interest. From the findings of this study, we concludes that cross carpeting or political party defections in recent times have made the electorates lost faith in their representatives especially at the lower house of legislature. It has resorted into a situation where lawmakers at the lower house have been object of ridicule, laughter and shame because of the way and manner they defect without any sense of national interest. Based on the theoretical and empirical findings of this study, the following recommendations were made:

1. All political parties should strive to have ideologies, programmes and policies which will serve as a compass to their members and discourage them from defecting to another party.

2. For democracy to thrive, political parties must be organized and run strictly according to constitution binding them.

3. Politicians should exercise patience and show maturity in the way the play politics. Defection to a ruling party may lead to one party system which is not healthy for the political development of the nation.

4. A legal cum political reforms are more apt today than ever before to institutionalize internal democracy, do away with overbearing godfathers' and place sanction on defection of elected officials from one party to another.

5. To ensure political stability in the country, Nigerians should not see politics as a business but as a call to serve and help distribute fairly the resources that are given by God.

\section{REFERENCES}

Adejumobi, S. (2004). Democracy, Good Governance and Constitutionalism in Africa. In S. Odion-Akhaine (ed). Governance: Nigeria in the World. Lagos: Centre for Constitutionalism and Demilitarization. 


\section{Ugo Chuks Okolie}

Ajayi, A. \& Ojo, E.O. (2014). Democracy in Nigeria: Practice, Problems and Prospects. Developing Country Studies, 4 (2), 107 - 125.

Ake, C. (1996). Democracy and Development in Africa. Washington, D.C: The Booklings Institution.

Aleyomi, M.B. (2013). Election and Politics of Party Defection in Nigeria: A Clue from Koji State. Covenant University Journal of Politics and International Affairs, 1 (1), 113 - 130.

Awofeso, O. \& Irabor, P.A. (2016). Party Cross-Carpeting in Nigeria's Fourth Republic: Cases and Causes. Journal of Public Administration and Governance, 6 (3), 31 - 43.

Awofeso, O. \& Irabor, P.A. (2017). The Game Theory and the Politics of Cross Carpeting in Nigeria's Fourth Republic. Public Policy and Administration Research, 7(7), 66-72.

Badejo, B.T, \& Obah-Akpowoghagha, N.G. (2015). The Impact of Cross Carpeting and Multiplicity of Political Parties in Nigerian Democratic Process. Journal of African Studies and Development, 7 (8), 215 - 230.

Beuir, M. (2010). Encyclopedia of Political Theory. Los Angelus: Sage Publishers.

Busia, K. \& Hadley, N. (2010). Party Switching and the Goals of Members in US Congress. San Francisco, CA: Paper prepared for WPSA.

Chang, A. (2009). Reelection Incentives and Defection: Party Switching in the Japanese Liberal Democratic Party. Japan: Institute of Political Science.

Desposato, S. (2006). Parties for Rent? Ambition, Ideology and Party Switching in Brazil's Chamber of Deputies. American Journal of Political Science, 50(1), $62-80$.

Dike, V. (2003). Nigeria and the Politics of Unreason: Assassinations, Decampments and Moneybags. Retrieved from http://www.nigerdeltacongress/articles/nigeria-and-thepoliticsof-unre.htm.

Edet, L.I. (2017). Politics of Defection and its Implications on Nigeria's Democracy. International Journal of Humanities \& Social Science Studies, 3(5), 375 - 285.

Egharevba, M.E. \& Chiazor, A.I. (2013). Political Corruption and National Development in Nigeria International Journal of Social Sciences and Humanities Review, 4 (1), 14 - 23.

Ekekwe, E. (1986). Class and State in Nigeria. Lagos Longman.

Eme, O.I. \& Ogbochie, A. (2014). The Legl/Constitution Basis of Political Party Defection in Nigeria. Kuwait Chapter of Arabian. Journal of Business and Management Review, 3 (11), 19 - 34.

Harriman, T. (2006). Is there Culture for Democracy in Nigeria? Test of a Public Lecture Delivered at the Dept. of International Development. Oxford University, Monday $5^{\text {th }}$ June. 2016. 
Iyare, T. (2004). "An Overview of Political Parties in Nigeria". In S. Odion-Akhaine (ed). Governance: Nigeria and the World. Lagos: Centre for Constitutionalism and Demilitarization.

Jinadu, A. (2014). "Political Parties and Democracy in Nigeria". In O. Obafemi, S. Egwu, O. Ibeanu \& J. Ibrahim (eds). Political Parties and Democracy in Nigeria. Kuru: National Institute of Policy and Strategic Studies.

Lenin, V.I. (1984). The State and Revolution. Moscow: Progress Publishers.

Mbah, P. (2011). Party Defection and Democratic Consolidation in Nigeria, 1999 - 2009. Afro-Asian Journal of Social Sciences, 2(2), $1-21$.

Mkpa, M.A. (2001). "Social and Cultural Systems in Nigeria". Inc. Ofuebe (ed) Dynamics of Social Studies. Enugu: New Generation Books.

Nomor, D.T. \& Iorember, P.T. (2017). Political Stability and Economic Growth in Nigeria. IOSR Journal of Economics and Finance, $8(2), 45-53$.

Nwanegbo, J.; Odigbo, J. \& Nnorom, K. (2014). Party defection and Sustenance of Nigerian Democracy. Global Journal of Humanities and Social Science, 14 (6), 1 - 8.

Okeke, R.C. (2017). Political Culture, Democracy and Development in Nigeria. Science Arena Journal of Politics and Law, 2 (4) 1 - 9.

Okoye, I. (2014). Incessant Defection among Politicians Worries Lawyers. Retrieved from www.dailyposting/2014/incessantdefection-among-politicians-worried-lawyer;htm.

Omodia, S.M. \& Egwemi, V. (2011). Party Politics and the Challenge of Political Representation in Nigeria. International Journal of Business and Social Science, 2(22), 270 - 275.

Omotola, S. (2009). Nigerian Parties and Political Ideology. Journal of Alternative Perspectives in Social Sciences, 1(3), 612 - 634.

Paldam, S. (2016). Does Economic Growth Lead to Political Stability? Retrieved from http://www.does-economic-growth.lead-topoliticalstabillity .

Parekh, B. (1993). The Cultural Particularity of Liberal Democracy. In H. David (ed.) Prospects for Democracy. London; Party Press.

Sodeine, G. (2009). No Regret for my Past Roles in Politics Omoboriowo. Daily Independent, May, 1.

Sottilotta, C.E. (2013). Political Stability in Authoritarian regimes: Lessons from the Arab Uprising. A Working Paper 13.

Udeuhele, G.I. (2015). Political Nonadism and its Implications on Political Development in Nigeria: A Critical Analysis. International Journal of African and Asian Studies, 1, 75 - 86.

Udo, J.I. (2014). The Strategy of Defections and Valueless Politics in Nigeria. Premium Times, Thursday, February 28, p. 8. 


\section{Ugo Chuks Okolie}

\section{Conflicting Interest Statement}

All authors declared that there is no potential conflict of interest on publishing this article.

Funding

None

\section{Publishing Ethical and Originality Statement}

All authors declared that this work is original and has never been published in any form and in any media, nor is it under consideration for publication in any journal, and all sources cited in this work refer to the basic standards of scientific citation.

Cite this article as:

Okolie, U. C. (2021). Cross Carpeting and the Challenges to Democratic Culture and Political Stability in Nigeria's Fourth Republic. The Indonesian Journal of International Clinical Legal Education, 3(3), 301320. https://doi.org/10.15294/ijicle.v3i3.48270 